\title{
LINKING PAST AND FUTURE \\ CULTURAL EXCHANGES AND CROSS-CULTURAL ENGAGEMENTS IN FOUR ASIAN MUSEUMS
}

\author{
CAROLINE TURNER
}

D ramatic change, geopolitical, economic and cultural, marked late twentiethcentury Asian countries. In this article I will discuss how four Asian museums - two in China and two in Japan - are participating in cultural exchanges and engaging crossculturally in their exhibition and curatorial programs in ways which negotiate past and future for their communities.

How does a museum in the twenty-first century celebrate and at the same time transcend history? How does such a museum engage productively with other cultures internationally and with ethnic minorities within a country, in ways that ensure justice and sensitivity?

The issue of cultural identity has often been associated in both Asian and Western museums with the concept of 'nation' and also, perhaps inevitably, with the idea of a 'homogeneous' society and culture within nations. Enshrined values of the dominant culture and ethnographic perspectives towards 'the other', especially minority cultures, often do little justice to contemporary and changing living cultures inside and outside national boundaries. In Australian museums, for example, the issue of reconciliation with Indigenous peoples is of profound importance, as is the need to represent increasing cultural diversity within a multicultural country. Although progress has been made over the last twenty years, these issues have not been resolved, as debate at the time of the opening of the new National Museum of Australia in 2001 revealed. The Asian museums which are the subject of this article, I will argue, are taking a leading position in reconciling past and future for their communities, as well as being at the cutting edge of developing models in their exhibition and curatorial practices for engaging productively with other cultures internationally or ethnic minorities within their own countries. ${ }^{1}$

Museums have to be contextualised in terms of their own histories as much as do the objects on display in those museums. The role of state and community groups is a critical factor in understanding those histories. The Shanghai Museum, founded in 1952 and born out of war and revolution, was, and indeed still is, a product of Communist China. Now recognised as one of the great museums of the world, its new building, opened in 1996, is also a symbol of China's future as an international cultural powerbroker and superpower. The Shanghai Art Museum, its sister institution, has a history of forty years of working with local art, often through bureaucratic associations of artists, but is now, through the Shanghai Biennale of 2000, taking on a role of international engagement and becoming a site for debate of controversial issues which give it a leadership role for art museums in China in the twenty-first century. The National Museum of Ethnology (Minpaku), Osaka, Japan, founded in 1974, emerged from post-occupation Japan. This was an era when the Japanese economic miracle had brought extraordinary confidence and allowed Japan to join the first world community and challenge Western notions of 'Asian' economic 
and cultural dependency. It now holds the largest collections of ethnological material from the second half of the twentieth century of any museum in the world and is developing policies redefining the nature of the genre of ethnological museums. The new Fukuoka Asian Art Museum, opened in 1999, is a product of Japan's postmodern present. It has been a pioneer in contributing to the emergence in Japan and internationally of appreciation of contemporary Asian art, and is at the forefront of critical debates regarding a new paradigm for Asian art.

\section{THE SHANGHAI MUSEUM: ASIAN PHOENIX}

Nowhere are the dramatic changes in twenty-first century Asia more apparent than in Shanghai, a city of 19 million people (China's largest city) dominated in its skyline by the futuristic television tower 'The Pearl of the Orient' in the twin city of Pudong. Yet just as appropriate a symbol of Shanghai today is the new Shanghai Museum, opened in 1996.

Designed by Xing Tonghe of the Shanghai Architectural Institute at a cost of 70 million Chinese Yuan (approx. AUD\$15.5 million) - eighty-five per cent from government and the other fifteen per cent "by generous donations from home and abroad" the building is in the centre of one of the city's most impressive plazas, Peoples' Square. Covered in pink granite and with a construction space of 39, 200 square metres, its architectural form is circular on a square base, in line with the Chinese philosophy of a square earth under a round Heaven. ${ }^{2}$ The design is also derived from a 'ding', one of the ancient storage and offertory vessels from Bronze Age China (eighteenth to third centuries BC).

It is not just the striking and futuristic building, however, which has led the Shanghai Museum to be regarded as one of the most dynamic museums of Asia. That reputation rests on the collections built up in times of extreme difficulty, and even more on the influence the Museum has had international- ly through sending exhibitions all over the world since 1980. Unlike the Palace Museums in Beijing and Taipei with their inherited collections, the founding of the new Shanghai Museum in 1952 was a deliberate decision on the part of then Mayor Chen Yi. In an article for the Art Newspaper at the time of the official inauguration in 1996, Jason Kaufman notes that many of the original collections came from those fleeing China who sold their works at bargain prices. ${ }^{3}$ Nevertheless, it seems all the works were paid for and, as I shall argue, the decision to establish the Museum was a stroke of great prescience. The result was of critical importance to China at a time when so much of Chinese cultural heritage had been removed to Taiwan. The city's collection was augmented by important archaeological discoveries (acknowledged to have helped reshape thinking in the West on China's past), purchases of works within China which might otherwise have gone to Hong Kong or to Western museums, and supplemented in the 1990s by a new freedom to purchase abroad and by a recent influx of gifts from expatriates. One of the reasons the Shanghai Museum collections are so respected internationally is the breadth of research and scholarship which has gone into building and explaining them. Shaping the collections, however, has not been an easy task.

I first went to China and met then Director, Dr Ma Chengyuan, in 1984. Then everyone in Shanghai and throughout China still wore Mao suits and the extraordinary construction boom had yet to begin. The Museum (like most municipal institutions in China) was in a run down and shabby building - a former bank on Henan Road. Nevertheless, the displays were of high quality and the scholarship demonstrated in the labels and publications spoke of tremendous commitment on the part of Director and staff. During the Cultural Revolution Dr Ma and his staff had been under serious physical threat from the Red Guards, and he had chosen to sleep with the objects in the Museum to try to protect them. In an interview with 
the Far Eastern Economic Review in 1996, he stated that the Red Guards had in fact locked him inside the Museum for several months as punishment for being a "suspected class enemy". ${ }^{4}$ However, it seems the Red Guards did not try to destroy all relics, and at a later stage would ring up Dr Ma after they had broken into a collector's house to tell him to come and see if there were any relics worth saving before they started smashing everything. The complexities of this era of political ferment and challenge to authority, by workers' groups as well as Red Guards on the local Shanghai level, needs more research, but suffice it to say that there is no question that saving a priceless heritage for future generations of Chinese has clearly been the mission of Dr Ma throughout his tenure at the Museum. He has also overseen many of the archaeological discoveries and international exchanges which have made the Museum's reputation, as well as the planning for the new building opened in 1996. His contribution has been immense and commands much respect internationally.

Today, there are over 120,000 pieces of art in the collection, and the Museum is divided into eleven permanent collection galleries each consisting of extraordinary objects: ancient Chinese bronzes, ancient Chinese sculpture, two galleries of Chinese ceramics, ancient Chinese jade, painting, calligraphy, seals, coins, Ming and Qing furniture, and Minority Nationalities. The Museum's bronzes collections, in particular, are justly famous: many are technological and artistic masterpieces, beautifully cast and with exquisite decoration of geometric and zoomorphic designs. Each gallery also has stunning display techniques and lighting effects, rivalling any museum in the world today.

This is a museum where it is difficult to resist superlatives, especially when one considers the astonishing development over a short period of fifty years. We need to see the Shanghai Museum's achievements, acknowledged by foreign observers, in the context of many much more static and conservative museums of Asian art worldwide, where the art works may be of high standard but there is little interpretation or ongoing cutting edge research. At the Shanghai Museum there are library, conservation and research areas (and a wonderful scholars' garden complete with rocks, a tea house and artificial lights simulating stars). Education and training are a critical aspect of the Museum's mission, as are symposia; and the new Museum has bilingual labels and a digital audio tour in eight languages. Computers are much in evidence in the new Museum and there are theatres and a high definition graphics hall for videos and educational films. Programs for school children are a key aspect of outreach (and a high proportion of the visitors are from schools). The scientific conservation laboratories have developed from a small laboratory in 1960 to a major research institute dating and conserving paper, metal, lacquer, wood and stone and publishing important papers related to this scientific research. The archaeology department has worked on twenty-seven historical sites, including local sites proving Shanghai had a culture in ancient times, something not previously well understood.

Equally impressive is the Museum's international outreach. The Shanghai Museum has, since 1980, been sending exhibitions abroad not as fundraising or empty cultural relations exercises, but in a genuine scholarly and cultural exchange from which many museums abroad have benefited and learned much. This has been a major factor in the Museum's international influence: since 1980, the Shanghai Museum has sent over fifty exhibitions to sixteen countries in Asia, America, Europe and Oceania (Australia and New Zealand) and also held sixty art exhibitions in Shanghai from outside, including contemporary art from Europe and Australia. I worked with Director Ma and staff in 1990 on one of these exhibitions of bronze treasures, which was shown in Australia as part of the Museum's international program, and on the return exhibition of contemporary 
Australian metalwork, which was shown at the new Shanghai Museum in 1997 as one of its first international exhibitions in the new building. I came to appreciate at first hand the professionalism and scholarship that characterised the Shanghai Museum's dealings with museums abroad. (For example no fee was charged for this exhibition at a time when many Western museums were charging hundreds of thousands of dollars on top of freight and other costs for exhibitions from their collections). Nevertheless, as with any exchange with any country, a framework of national and political realities has to be taken into account. Both the Queensland exhibition of 1990 and an earlier San Francisco exhibition of 1983 were in response to sister state and city initiatives that included trade agendas on the Australian, US and Chinese sides, and the catalogue published by the Queensland Art Gallery in 1990 carries the corrigendum: "Despite the different colours used in this map, Taiwan is acknowledged to be part of China" - an issue avoided by the US museum catalogue which used black and white maps. ${ }^{5}$

One of the Museum's most interesting display areas is the gallery devoted to Minority Nationalities' art, although minority art is integrated into the other displays, especially in the Bronzes Gallery. There are fifty-five officially recognised ethnic minorities, that is, not Han Chinese, in today's China, about eight per cent of the population, equalling at least 70 million people. Of the twenty-three provinces of China (Taiwan is the twentythird), five are Autonomous regions. Dr Ma initiated a policy of exhibitions of the art and culture of minority peoples and of exhibitions from Autonomous regions and to date three major exhibitions have been held - from Xinjiang, Mongolia, and Tibet. Exhibitions of the art and culture of minorities pose a challenge for any museum, including in Australia as already noted. The display of the culture and art of ethnic minorities is inevitably related to government policy in every museum worldwide. Official policy in China is that all ethnic groups are equal and that local nationalisms should be opposed. From a museum professional's perspective the fact of showing those cultures and the way in which those cultures are presented, and whether respect for achievement is accorded, are critical issues. Dr Amareswar Galla, Australianbased President of the International Council of Museums' Asia Pacific chapter, maintains that the Shanghai Museum is leading the way in opening up Chinese museums to representation of autonomous minorities. ${ }^{6}$ The fact of having a permanent gallery of Minorities' art is impressive and the Shanghai Museum certainly sets a high standard with regard to presenting the art of minority peoples. Since most are from Western regions of China, their artistic production may not necessarily be well known or understood in the East, such as in Shanghai.

Dr Ma curated the first major exhibition from Xinjiang Uygur Autonomous Region with the Museum staff (including, as is clear from the catalogue, ethnic minority staff). In no sense is the approach 'anthropological' the works are presented as art objects in a formal sense. The exhibition catalogue in Mandarin and English presents a panorama of extraordinary and beautiful objects sculpture, painting, calligraphy, jewellery such as gold and beads, ceramics and textiles, including exquisite embroidery. It also delineates the civilisation and cultural exchanges in the region of the Silk Road over centuries and in particular recent archaeological research (especially, the catalogue emphasises, finds since the implementation of "the policy of reform and opening to the outside world") including by a Sino-Japanese joint project. Among the most fascinating objects are documents in Chinese and Aramaic systems and languages including Kharosthi, Sanskrit, Khotonais, Koutcheen, Sogdian, ancient Tibetan, ancient Uygur, and Qarakhanid. The splendidly illustrated and researched volume can be read as a celebration of cultural exchange within and outside China. 


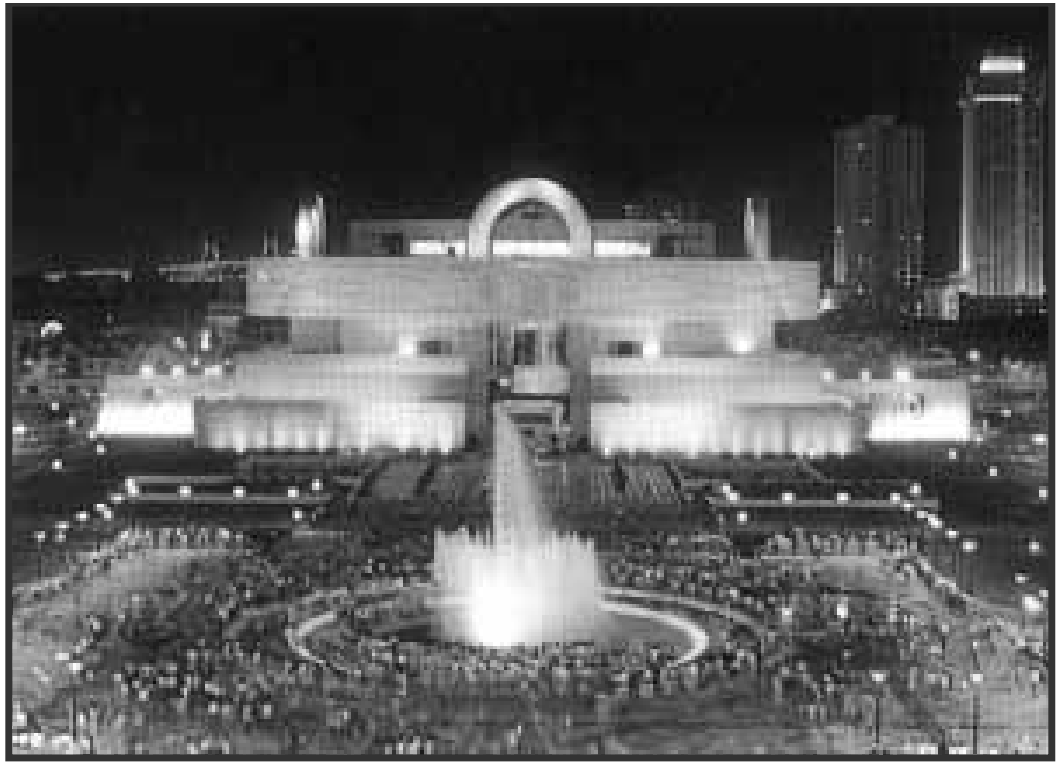

Shanghai Museum at night. Photo: Shanghai Museum.

The displays and information throughout the Museum and in catalogues produced for international exhibitions constantly talk in terms of engagement with other cultures and exchange of ideas, including, for example, in relation to the importation of Buddhist ideas, the influence of these ideas from India, Pakistan and Afghanistan on Chinese art and their adaptation in the Chinese context. The displays in the bronzes area likewise talk of bronzes found in border areas, showing valuable evidence of cultural exchange. Artworks from the Tang era are described as revealing that dynasty's tolerance of other cultures, allowing settlement by foreigners and its openness to Western ideas. Thus the Museum displays and publications stress a rich heritage, not only of China's influence on other cultures but also of border crossings leading to culture exchanges and of the enrichment of Chinese culture from other sources, including minority peoples' culture.

The Shanghai Museum's overall focus then is on dynamic exchange as part of China's cultural history. This approach opens up new ways of seeing national culture. What is presented is a complex multi-layered history which gives evidence of cultural crossings over the centuries. Moreover, the Museum's own history is an inspiring story of survival and resurgence: it has reclaimed and rewritten history through scholarly research, including the local history of Shanghai; asserted the importance to community of this history; defended China's culture against iconoclasm; combined history and the past with living culture (and symbolised this with its stunning architectural design); and made an effort at cultural inclusion on the basis of reasonable equality. The Shanghai Museum gives a possibility of examining history in the context of 4,000 years, a history which might otherwise be lost. Its international exchanges include a contemporary focus on living cultures and contemporary art from abroad. It thus shows a living face and breaks down the barriers between past and present, dead art and living culture. There is a somewhat ambiguous Chinese saying that whoever controls the past controls the future. The Shanghai Museum's efforts at researching and preserving the past are, without question, an important contribution to China's future.

The Shanghai Museum is also an example 
of the strength of survival of scholarship and thus a symbol of survival for all museums. While working within official policies, and with a strong relationship to local Government in Shanghai in particular, the Museum has won international respect. A new arena for the Museum is opening up in the critical area of training in the Asia-Pacific region. The Museum will host in 2002, for international participants, an International Council of Museums (ICOM) workshop, in partnership with the Asia-Pacific Executive Board of ICOM, on globalisation and conservation of intangible heritage. This gives it a leadership role in shaping Asia-Pacific museum dialogue, including on issues of representing diversity and minority cultures. ${ }^{?}$

THE SHANGHAI ART MUSEUM AND BIENNALE: AT THE CROSS ROADS

If the Shanghai Museum negotiates past and future with deceptive ease, the Shanghai Art Museum by contrast represents the disaffections and divides of contemporary art in a rapidly changing society. It has become a site for the negotiation of ideas of living artists trying to find a pathway through the complexities of the present. While the Far Eastern Economic Review described a hushed crowd at the opening of the Shanghai Museum in 1996, the opening of the new Shanghai Art Museum four years later, which coincided with the opening of the Third Shanghai Biennale on 6 November 2000, presented a quite different scene of noisy debate and even challenge to authority. It has been described as "one of the defining moments in contemporary Chinese art". 8

Although China was never colonised it was subjected to the indignity of encroachments from 1842 onwards by Western imperialist powers and finally by Japan. Shanghai was a centre of foreign 'concessions' and of Western and Japanese trade and influence prior to the Second World War. The 2000 Biennale, which inaugurated a new direction for the Museum, was also the opening exhibition in a new facility for the Art Museum now located in a former art deco library built in the 1930s, the era of foreign control. It is ironic that the Museum is the new building and the contemporary art museum the old building; but there was a certain sense of historic appropriateness in that the old building represented Shanghai's semi-colonial and cosmopolitan past, while the new Art Museum was inevitably to become a site for 'postcolonial' reaction. The Shanghai Art Museum was founded over forty years ago, so it was already a postcolonial institution. Its own collection is of Chinese art, including a fine representation of the school of Shanghai from the early twentieth century. The First and Second Shanghai Biennales, held in the previous inadequate premises, had been devoted only to Chinese art and largely to traditional Chinese art. The Third Shanghai Biennale, in combination with a challenging series of satellite shows, chose deliberately to address issues of globalisation, regionalism and local identity in a postcolonial world.

The Third Shanghai Biennale in such a vital centre and city as Shanghai was immediately recognised as a very important event by foreign curators, including myself, who flocked to the event. The exhibition was put together by a team of curators, including some from Shanghai and two from overseas. The local Chinese curators were, Fang Zengxian, head of the curatorial team, Zhang Qing and Li Xu. The overseas curators were Hou Hanru, an expatriate Chinese curator of considerable international reputation, living in Paris, and Toshio Shimizu, also a very well-known and respected curator internationally, based in Tokyo. Major sponsorship also came from Japan. Hou Hanru and others saw the Biennale as a breakthrough because, as Wu Hung, a scholar at Chicago University has argued, it broke long-standing taboos about who controlled contemporary art in China. ${ }^{9}$ In an era when boundaries are breaking down and change, fluidity and mutability are the order of the day, this internationalisation of the Biennale was seen as a victory for the concept that art can be appre- 
ciated for itself rather than only as part of a local or national context. Yet the situation regarding contemporary art is fluid and unstable and there was much at stake here, not simply whether older artistic bureaucracies should continue to control the art scene, but also issues of engagement and freedom in a much broader sense. Interestingly the great majority of artists was Chinese, with Japan the country next most dominant in numbers; but the selection included not only European and American art, but several artists from elsewhere in Asia. Indonesian artist Heri Dono won a major award, and two Indigenous Australian artists (the only Australians represented) were included - Emily Kngwarreye and Gordon Bennett. Taiwanese artists were included in the Shanghai Biennale (something only possible since the late nineties), identified as from, for example, "Taibei, Taiwan, China".

At the official opening of the 2000 Biennale, nothing could strike one more forcibly than the refusal of many of those locals present to listen to the official speeches. One Western critic leapt on a chair to call for silence but was completely ignored. If government presence had given the new Shanghai Art Museum its building and funding, many Chinese artgoers at the new Museum were, it seemed, determined to ignore that fact. Of course this lack of interest in official speeches did not necessarily signify lack of support for the Biennale and is not unusual at contemporary art shows worldwide. Although the banquet, sponsored by Coca Cola, was more relaxed, the symposium that followed was not. Wang Nanming, in a paper entitled "The Shanghai Art Museum should not become a market stall in China for Western hegemony", argued that the Western world was forcing Chinese art to conform to its own image and the Shanghai Art Museum, in which the symposium was taking place, should first of all be concerned with Chinese art and not the Western marketplace. ${ }^{10}$

Yet the catalogue essays, especially by Chinese curators, had already made the point that in no way was the Biennale to blindly follow 'the West'. The emphasis of the Biennale was that it would go beyond Westcentrism and also embrace a new internationalism. This was made quite explicit when Hou Hanru posed the key question (a question undoubtedly circumscribed by the politics of the Biennale which needed government backing): "In today's post-modern world, Shanghai serves as a model for a new specific and indispensable position in the cultural negotiation between global and local cultures in non-Western societies. In this negotiation a 'core' question is often raised: 'What is Oriental modernity?.""1 Many artists and curators, including Hou Hanru, today are working beyond the nation and beyond East and West. Hou Hanru's question regarding Oriental modernity was brilliantly insightful in the context in which the Biennale was being held. He described to me his emotion in coming back to Shanghai to work on international contemporary art, and his personal journey since leaving China and now returning to help begin a process of connection. This is the eternal dilemma of the expatriate. In an interview with Zhu Qi, Hou Hanru also stated:

\begin{abstract}
Artists should not make art that is just easily accessible to the public. Today, the intellectual no longer exists. Even more tragic, is happiness has ceased to exist ... exhibitions lacked, just like Chinese culture as a whole today, a sense of humour, an unbearable lightness of being ... I think today's art in China is too utilitarian, over-mediated. There is no personal freedom to look at and evaluate the root of a problem or issue. ${ }^{12}$
\end{abstract}

The Biennale was an exciting and diverse exhibition of international contemporary art, including Chinese art. More controversial were the satellite shows and especially the alternative Biennale (with its own curators and not in any way part of the official 
program) held in a disused warehouse near Suzhou creek. As Western critic David Barrett noted:

\begin{abstract}
There are several reasons why this show was so talked about: it presented work by the youngest artists; it took an aggressive stance towards the Biennale; and it was deliberately shocking. All these attributes were embodied by the exhibition's succinct title: $F^{* * *}$ Off. (The translation was a brilliant underplay; the Chinese title was The Uncooperative Attitude.) ... Recombined horses, diseased and wounded humans, tests of physical endurance, raw flesh. These were the enduring images of $F^{* * *}$ Off. ${ }^{13}$
\end{abstract}

Rotting meat and its stench were indeed the keynote of this alternative exhibition and the rumour spread that the authorities, who had closed many such shows in the past on opening night, had allowed this one to remain open as a test of endurance for foreign curators and locals alike!

The artist Ai Weiwei, a member of the post-Tiananmen diaspora and one of the organisers of the alternative Biennale, provides an insight into the sense of disillusionment with contemporary Chinese art which undoubtedly partly inspired the alternative Biennale, declaring in an article in 1997 that the "history of modern China is a history of negation, a denial of the value of humanity, a murder of individuality. It is a history without a soul", in which artists "reflect degraded standards and a lack of heartfelt values". ${ }^{14}$

The whole Biennale, including the alternative shows not part of the official Biennale, was correctly seen as a test case for freedom and internationalism within contemporary Chinese art. The robust debate was in itself a breakthrough and an indication that Chinese contemporary art and the city of Shanghai were becoming a vibrant force to be reckoned with in the international art scene. The international interest also reflected the impact of Chinese artists on the world scene since the post-Tiananmen diaspora sent them to exile in Europe, the US and Australia. The fact that so many are returning to exhibit in Shanghai or were involved in the Biennale and alternative Biennale, signalled a new beginning. (This international focus is continuing with a European and a New York curator working alongside Chinese curators for the 2002 Biennale).

ENGAGING WITH THE WORLD: THE NATIONAL MUSEUM OF ETHNOLOGY (MINPAKU) OSAKA, JAPAN

The Japanese National Museum of Ethnology (Koruritsu Minzokugaku Hakubutsukan known as Minpaku) was founded in 1974 (and opened in 1977) as an anthropologically focussed and ethnological museum on the site of the former Osaka 1970 World Expo. An Inter-University Research Institute under the Japanese Ministry of Education, Culture, Sports, Science and Technology, it has been recognised as one of the top 100 public facilities in Japan. It is an example of both a university research centre and a hightech museum created out of the wealth of Japan's post-war recovery and the resurgent economy of the 1970s in Japan's second largest city of Osaka, a powerhouse of industrial energy with a population of over 2.5 million.

Like many Japanese museums of the second half of the twentieth century, Minpaku is characterised by stunning architecture. Designed by Kisho Kurokawa to harmonise with the Senri Expo Park, the emphasis is on horizontal roof lines to suggest traditional Japanese eaves. In contrast to the Shanghai Museum, which covers only China in its permanent exhibitions, and the National Museum in Tokyo (Tokyo Kokuritsu Hakubutsukan known as Töhaku) founded in the nineteenth century which is a Museum of Oriental arts and of the Imperial Household, the National Museum of Ethnology, Osaka, like the Expo before it, covers the world. The museum "aims to promote a general under- 
standing and awareness of people, societies and cultures throughout the world". ${ }^{15}$ Its staff are engaged in extensive fieldwork internationally in many countries including, for example, research into Aboriginal cultures in Australia. One leading scholar, Professor Masatoshi Kubo, has been visiting Aboriginal communities for over a decade to study their languages. There is not, however, unlike many older ethnographic museums, a hierarchy between cultures; and the lifestyles of Europeans and Japanese are included in the displays, although undoubtedly the emphasis is on 'folk' culture and festivals rather than modern urban cultures.

Education is a special issue here as everywhere in Japan. The Museum holds numerous symposia, mainly for academics. It has an international reputation as a major university research centre and has a graduate school. Public education programs operate on several levels, including for schools, and multimedia is very much in evidence, but there are no specialist education staff. Like its sister institution, the National Museum of Japanese History at Sakura, outside Tokyo, it is heavily focussed on university-style academic research and training; but Minpaku's focus on other cultures evades the torment experienced by the history museum which ends its exhibits in the 1920s because no way has yet been found to address the highly sensitive issues in Japan of the Second World War.

This academic and research orientation of Minpaku is both a strength and a weakness. Moreover, attendances have been dropping in recent years, possibly because of the out-ofthe-way location in the former Expo Park, although the Museum staff attribute the drop in part to the effect of television documentaries. In an effort to reverse the attendance figures downturn, the Museum is planning to do a series of international exhibitions. The first, timed to coincide with the World Cup jointly hosted by Japan and Korea, is about contemporary Korean lifestyle and is an interesting example of the Museum's emphasis on living culture. A whole Korean house is to be imported. The question might be raised whether Korean contemporary lifestyle is so different from lifestyle in Japan but it may also be that the average Japanese knows little of the contemporary lifestyle of Koreans, given the divisions that still exist between the two nations as a result of Japan's colonisation of Korea. One might also ask whether the exhibition will feature the lifestyle of the large Korean population living in Japan who still experience discrimination with regard to political rights. However, the Museum is undoubtedly moving to tackle some of the very difficult issues related to display of other cultures.

The issue of cultural identity in museums, as I have already suggested, is tied to that of 'nation' and the idea of a homogeneous society and culture. The values of the dominant culture and ethnographic perspectives towards 'the other', especially minority cultures, often do little justice to living cultures. Here, however, the Minpaku record is impressive.

One example is the championing of the culture of the Indigenous people of Hokkaido colonised by Japan in the nineteenth century. The National Museum of Ethnology has been displaying Ainu culture since 1979, when Ainu culture was not recognised as a separate entity. The Ainu are in fact a tiny population numbering less than 100, 000, and the Japanese Government was still maintaining in the 1990s that Japan was a monocultural country, until persuaded by Ainu activism to retract this position.

However, the Museum was well ahead of these changes and has assisted in setting up new Ainu museums in Hokkaido, at least one of which is run by an Ainu board. Another of these museums is largely the inspiration of Shigeru Kayano, the only Ainu person elected a member of the Japanese Parliament and an Ainu activist, who is also a major adviser to Minpaku on Ainu culture. Professor Kazuyoshi Ohtsuka, of Minpaku's staff, is a leading expert on Ainu culture and assisted in the development of the Hokkaido 


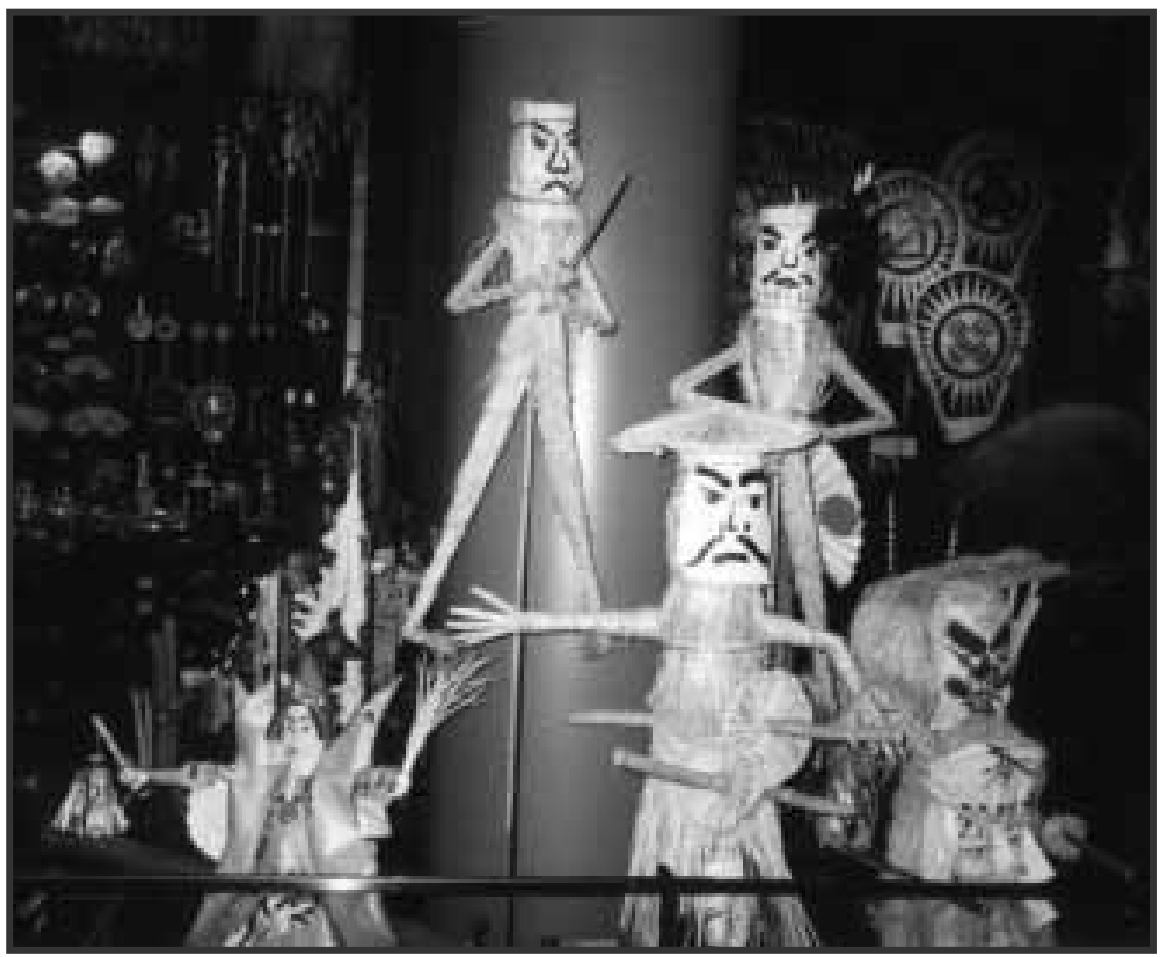

The emphasis at the National Museum of Ethnology, Osaka, is on living culture including festivals and 'folk' culture. Photo: Caroline Turner.

Museums. He is a key figure in researching and presenting Ainu culture and his displays at the National Museum of Ethnology are both culturally sensitive and allow real insights into Ainu culture and society. He also believes in living culture and will be bringing one hundred contemporary Ainu artists together in the first permanent exhibition of their art works with those of traditional artists who influenced them. This exhibition will be epoch-making by allowing Ainu to select what should be exhibited; previously this was done solely by Japanese curators. The Ainu people are regarded in Minpaku as the absolute owners of the Ainu collections, and five Ainu artists are brought in every year to scrutinise the collections. ${ }^{16}$ As Elaine Gurian has argued, the involvement of native peoples challenges fundamental rules of museums ${ }^{17}$ and Minpaku's policy here is in advance of many museums worldwide.
As a museum primarily of the twentieth and twenty-first centuries, Minpaku also questions differences between art and ethnology and even what ethnology and ethnography mean in a twenty-first century context. As Kenji Yoshida notes, the Museum has some nineteenth-century colonial type collections, such as those from Melanesia, but the majority of the collections are contemporary, that is, the last fifty years. While its collections are smaller than those of the Ethnological Department of the British Museum or some of the great European ethnology museums such as the Musée de l'Homme, Paris or Museum für Völkerkunde, Berlin, it is the world's largest ethnological museum of the second half of the twentieth century. ${ }^{18}$ This focuses much of the research on the modern era. The impressive Images of Other Cultures curated by Kenji Yoshida and John Mack from the British Museum offers an example of a new direction and way forward for museums. ${ }^{19}$ In 
his catalogue essay Yoshida argues it was unfortunate that the Japanese adopted what he sees as the Western notion of seeing other countries and cultures as exotic or alien. Of course, as Yoshida points out elsewhere, this is a worldwide issue for ethnographic museums: one Swiss museum has changed its name from a museum of ethnology to a "multicultural museum". ${ }^{20}$ The National Museum of Ethnology accepts that its displays are beset by a legacy of cultural relativism but does seek to go beyond this, in particular by including Japan and Europe in the displays and not seeing cultures as static. Contemporary Indigenous art and cultures are included as well, for example, the work of the Australian urban and activist Aboriginal artist Lin Onus, of Yorta Yorta descent, (now deceased) and Gordon Hookey (Waanyi language) whose painting Native Title Fight (1999) points to difficulties of Australian reconciliation with Indigenous peoples and continued racism in Australia. The artists' Aboriginal language groups are acknowledged (something not always done in Australia) and the information sheet has the artist's words, not a mediated curatorial version. ${ }^{21} \mathrm{~A}$ process of inclusion means also a fundamental reassessment of contemporary cultures, such as the modern shields from Papua New Guinea displayed in the Images of other Cultures exhibition with their references to beer and football.

The dominant feel of the open and frequently touchable displays at Minpaku is of vibrant displays of living culture and of a Museum and staff in touch with and often in advance of public attitudes especially towards other cultures and thus serving a vital educational role within its community.

WINDS OF CHANGE: THE FUKUOKA ASIAN ART MUSEUM AND FUKUOKA TRIENNALE

In 1274 and again in 1281 the Mongol Emperor Kublai Khan sent great invasion fleets to the part of Kyushu where the city of Fukuoka is now situated. On both occasions a typhoon wreaked devastation on the invad- ing armies. The Japanese called this divine wind that saved Japan on two occasions 'kamikaze'. This name has a more immediate association today with Japanese suicide pilots in the Pacific war, a war still remembered with considerable bitterness by many of Japan's Asian neighbours. But neither the ancient history of over seven centuries ago nor the more recent history of the last sixty years, characterise the mood of Fukuoka. Today, Fukuoka is a dynamic modern city of just over one and a quarter million people, exuding considerable prosperity, extremely cosmopolitan and a city committed to exploiting its position as a natural Japanese gateway to Asia. (It is three hours for example by hydrofoil to Korea and there are also direct connections to Shanghai). It is the only city in Japan, and one of the few in the world, with a museum devoted to contemporary Asian art.

The Fukuoka Asian Art Museum officially opened in 1999 is an offshoot of the Fukuoka Museum, and was constructed to house the parent museum's considerable contemporary Asian collections and be a site for the highly acclaimed Asian Art shows (now called Fukuoka Triennale) begun in 1979-1980. This was the first major show of this kind in any country and the most continuous, except for the Bangladesh Biennale. The collection, developed over more than twenty years, is the finest collection of contemporary Asian art in the world. The new purpose-built Museum is situated on the seventh and eighth floors of the Hakata Riverain complex, a magnificent new shopping centre in the up-market and central downtown area of Kawabata, known for its cinemas, bars, restaurants and designer fashion boutiques. The Museum has an excellent library, video and new media documentation centre and a research centre. One of its most successful programs involves residencies for Asian artists. Many of the programs are aimed at community, schools and young people. The Asian art fair generates a fun family image - for example Pakistani craftsmen 


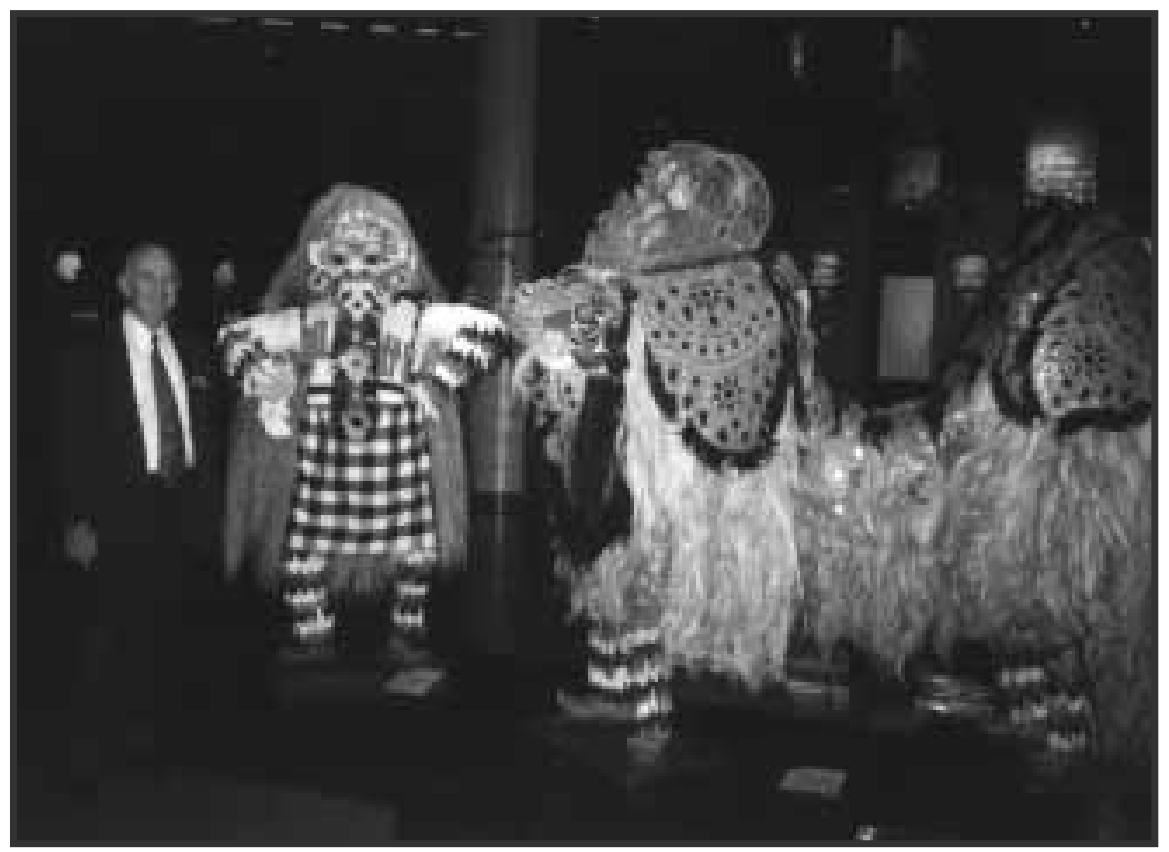

Visitors can move amongst the open access displays at the Osaka Museum, Japan. Photo: Caroline Turner.

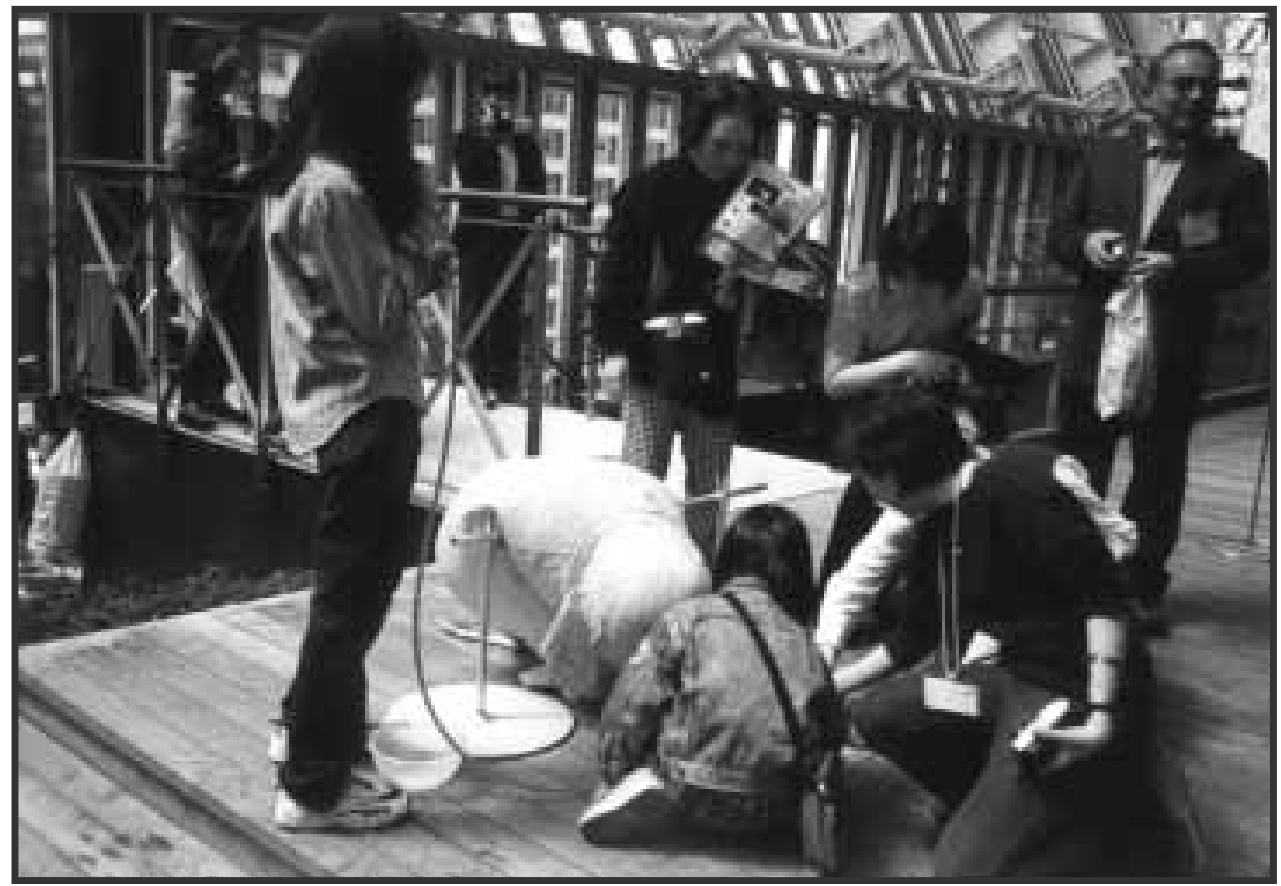

Fukuoka Asian Art Museum, Japan: art fair associated with the 2nd Fukuoka Trienniale. Photo: Caroline Turner 
decorating mobile phones for young adults, or children participating in an interactive display with blow-up rubber elephants created by a Thai artist. ${ }^{22}$ The Asian art shows have always been chosen by Fukuoka curators working with artists and curators in the different countries of Asia and a huge emphasis has gone to country visits and research.

The Fukuoka Triennale is supported by a number of organisations, including the Japan Foundation. The latter, through the establishment of its own Japan Foundation Asia Centre in Tokyo a decade ago, made a policy decision that Japan is part of Asia. This is significant because for many in Japan the nation has not been seen as part of Asia but in a position somewhat analogous to the UK in regard to Europe. The Asia Centre in Tokyo has funded joint projects all over Asia and the Asia Centre Gallery has made a special feature of exhibitions and symposia about contemporary Asian art.

The Fukuoka engagement predates this by another decade and the city Government has clearly played the key role in financing and supporting the contemporary Asian focus of the Museum. Its activities are thus very much concentrated on Fukuoka city and region although that does not diminish the Museum's significance or the contribution it has made to contemporary Asian art development, particularly in Asia, which, along with the activities of the Japan Foundation, has been monumental.

If the Fukuoka Triennale has a subtext that Japan is part of Asia or at least must engage with other Asian countries in a spirit of harmony and cooperation, another subtext of the exhibition is undoubtedly, I believe, that Japan is not necessarily part of the 'West'. While this is not an official policy, it is a thread running through much of the discourse surrounding the Triennale and this in turn echoes a common theme in contemporary Asian art of rejection of the 'Western paradigm'. At conference after conference I have attended over the last ten years in many countries in the Asia-Pacific region, the belief that contemporary Asian art should be about building a new approach to art is dominant in discussion. This is not, however, about building a wall around the region of Asia (a term used by Hou Hanru to argue against such a concept in one such conference $)^{23}$ or a rejection of international art merely a rejection of Western art ideas (and curators) continuing to dominate the international art world and its theoretical directions.

Masahiro Ushiroshoji, Chief Curator of the Fukuoka Asian Art Museum and one of the critical figures in the Asian Art shows, writes in the introduction to the catalogue of the collections of the new Asian Art Museum of the need to move away from older definitions of art imported from Europe. Describing Japanese history over the twentieth century, he writes "Japan aimed to build a modernised Western nation and carried out an imperialistic war of aggression in this region under the slogan: "Extricate from Asia, Join in the West'. This is a negative legacy". ${ }^{24}$ Ushiroshoji's vision for art has led to incorporation of craft with fine art in the exhibitions and curatorship of an extremely important exhibition, The Birth of Modern Art in South East Asia. ${ }^{25}$ This exhibition, for the first time, raised some of the issues about Japan's wartime role in the developing modern art of countries such as Indonesia and the Philippines.

Ushiroshoji urges a different model for art today: "the significance of an Asian art museum lies in the attitude of re-questioning the European centralized value system that dominates the space and system for art...". ${ }^{26}$ He points to the theme of the 4th Asian art show 1994, which included socially and politically challenging works under the title "Realism as an attitude", and to the emphasis on collaborations between artists.

The Birth of Modern Art in South East Asia, recent Asian Art Shows, and the Fukuoka Triennales focussed on issues of importance to Asia, not the West. In fact such an approach is unusual in Japan, where political 
and socially conscious art is a rarity and art exhibitions addressing the theme of the Pacific war almost non existent. The very concentration on 'Asian' artists is unusual. Just how radical the Fukuoka Asian Art shows and Triennales are in the context of Japan has not been clearly recognised in the art world or even in Japan, where the show is rarely referred to as a major art event and where it is often criticised as too community oriented. My contention is that the Fukuoka Asian Art Museum is without question a museum of the future, engaging with community but also addressing issues of social significance for that community's future, including multiculturalism. Japan's birth rate and population is falling and the possibility of immigration raises highly contentious issues within the country. Programs such as the ones I have described help create an understanding of other cultures which can have long term impact.

\section{CONCLUSION}

The above discussion points to the evolution of a non-Western museological discourse that is grounded in Asia, inclusive in both professional orientation and cross-cultural dialogue. These four museums are returning an Orientalist gaze, engaging internationally and shaping museological debate for museums in the Asia-Pacific region but with implications beyond the region. The Shanghai Museum is a centre of cultural stability, researching and displaying the past but introducing living culture, including that of minorities, and open to interaction on terms of equality with the rest of the world. The Japanese National Museum of Ethnology is breaking away from static culture to living culture and in the process tackling critical issues of defining culture and of minorities within countries, including Japan. For the Shanghai Art Museum the issue of the moment is internationalism versus local 'Chinese' art but this is likely to be transient, and the Museum has the opportunity to be a leader in art in China and internationally, especially by reconnecting with Chinese diaspora art and artists and by including other Asian artists in its exhibitions in the future. For the Fukuoka Asian Art Museum the issue of internationalism is encapsulated in a policy to overcome Japan's isolationism from Asia (and contested history when it did engage with Asia) in a brave and radical approach which is also potentially redefining Japan's artistic future as non-Western yet culturally inclusive.

\section{Endnotes}

1 In no way do I wish to imply that these policies have been imported. Asian museums today are not an offshoot of European museums or clients of EuroAmerican museum philosophies and aspirations. Asian museums are part of international networks and participants in professional debates on new roles for museums and new approaches to collection and display. The International Council of Museums (ICOM) and its Asia-Pacific chapter play a significant role. For information on Asian Museums see the Bulletin of ICOM Asia-Pacific (ASPACICOM Bulletin); see also Amareswar Galla (ed.) Protection of Cultural Heritage in Southeast Asia: Workshop proceedings, Hanoi, Vietnam, 9-13 April 2001, (ICOM-ASPAC, 2002).

2 Shanghai Museum Official Guide, (English version), n.d., p.3.

3 Jason Edward Kaufman "A glittering new museum for China (Shanghai)", The Art Newspaper, October, 1996, p. 8, (internet version at $<$ jasonkaufman.com $>$ ).

4 Pamela Yatsko, "Culture - Triumph of the Will", Far Eastern Economic Review, 7 November 1996, p. 48. The current Deputy Director, Gu Xiang Yu, noted in an interview with Richard McGregor in the Australian, 13 December 1996, that he had been a Red Guard and that young people then did not understand the importance of heritage.

5 Treasures from the Shanghai Museum, Queensland Art Gallery, 1990. See for an early US example of exchange, René-Yvon Lefebvre d'Argencé, Treasures from the Shanghai Museum: 6000 years of Chinese Art, Shanghai Museum and the Asian Art Museum of San Francisco, 1983.

6 Amareswar Galla, interview with Caroline Turner, June 2002. See also Shanghai Museum: Chinese Minority Nationalities' Art Gallery, (Shanghai Museum, set of boxed introductions to museum collections (Chinese and English), n.d.). See for the 
exhibitions: Archaeological Treasures of the Silk Road in Xinjiang Uygur Autonomous Region, (Shanghai Museum, 1998); Treasures on Grassland: Archaeological Finds from the Inner Mongolian Autonomous Region, (Shanghai Museum, 2000); Treasures from Snowy Mountains: Gems of Tibetan Cultural Relics, (Shanghai Museum, 2001). Of course 'minority' histories are presented in a frame that includes, especially in the Tibet volume of 2001, prefaces from political leaders regarding Tibet's status, for example, from Lek Chok, Chairman The People's Government of Tibet Autonomous Region, that the occasion marks "the 50th anniversary of the peaceful liberation of Tibet" while before this "liberation...Tibetan culture moaned for the sufferings under the cruel rule of the feudal slavery system with integration of politics and religion" (Forewords - not paginated). The introductory paragraph to the handbook on Minority Nationalities' art at the new Museum talks of the great contributions of minority cultures to: "our splendid and glorious Chinese civilization", also noting "assimilation of various nationalities", (a word, which, in the English translation, is an often resisted term).

7 For details see: $<$ http://www.asiapacific.icom.org $>$ or $<$ http://www.icom.org $>$.

8 Wu Hung, "The 2000 Shanghai Biennale: The Making of a 'historical event' in contemporary Chinese art" in Wu Hung (ed.), Chinese Art at the Crossroads: Between Past and Future, Between East and West, (London: New Art Media Ltd in collaboration with the Institute of Visual Arts, 2001) p. 275.

9 Wu Hung, "The 2000 Shanghai Biennale", p. 221.

10 Wu Hung, "The 2000 Shanghai Biennale", pp. 265-268.

11 Hou Hanru "Shanghai Biennale: A New Expression in a New Era", in Shanghai Biennale 2000 Shanghai Spirit, (official catalogue, Shanghai Art Museum, 2000), introduction page unnumbered. Zhang Qing, another curator, wrote in the same catalogue of "a growing cultural independence, forcefully challenging exhibitions with predominant Western perspective" (Zhang Qing "Beyond Left and Right: Transformation of the Shanghai Biennale", introduction page unnumbered).

12 Wu Hung (ed.), Chinese Art at the Crossroads, pp. 259-260.

13 Wu Hung (ed.), Chinese Art at the Crossroads, pp. 237-238.

14 Ai Weiwei, "Zuochu xuanze,"(1997) in Geremie $\mathrm{R}$. Barmé, In the Red: On Contemporary Chinese
Culture, (New York: Columbia University Press, 1999), p. 363.

15 Survey and Guide 2001, (Museum publication), p. 3; Kenji Yoshida, “'Tōhaku' and 'Minpaku' within the History of Modern Japanese Civilization: Museum Collections in Modern Japan”, in Tadao Umesao, Angus Lockyer, Kenji Yoshida (eds), Japanese Civilization in the Modern World, XVII, Collection and Representation, (Osaka: National Museum of Ethnology, 2001), pp. 77-102 . Kenji Yoshida, an African expert and Professor at the Museum, comments that the two museums are in many ways opposites, with the National Museum in Tokyo limited to the 'Orient' while the Ethnology Museum is truly global: one is art and the other aspects of everyday life and the collections of one can be designated 'treasure' and of the other 'trash.' (p. 100). He points out the Museum includes urban and rural but had a cut off with the introduction of plastics (p. 96) but this, I feel, can hardly hold for future displays considering that film and video are now so prominent in the collections.

16 Caroline Turner, interviews with Museum staff, March 2002. A Eurpoean museum director credits Kumei Sasaki, former director general, with a major role in Ainu displays.

17 Elaine Heumann Gurian "What is the object of this exercise", in Humanities Research, vol VIII, no.1, 2001, p. 31.

18 Yoshida, “'Tōhaku' and 'Minpaku' ”, p. 96.

19 Kenji Yoshida and John Mack (eds), Images of Other Cultures: Re-viewing Ethnographic Collections of the British Museum and the National Museum of Ethnology, (Osaka: NHK Service Centre, Inc., 1997).

20 Yoshida, “'Tōhaku' and 'Minpaku' ”, p. 101

21 Gordon Hookey (Waanyi language) "Native Title fight” 1999. The Museum's official handout states:

"The Native Title Fight painting is about Aboriginal resistance to Australian Government's oppression, continual colonialism and multi-national corporation's (sic) destruction to Aboriginal lands. It depicts a boxing ring in which a kangaroo kicks the snout off a pig whilst racist redneck politicians look on worriedly in disbelief'. The information sheet goes on to talk about Prime Minister John Howard, Pauline Hanson and racism in Australia and is obviously written by the artist although it is unsigned. Thus an Aboriginal person speaks for himself in the displays and not through the mediation of a Museum curator.

22 See: The 1st Fukuoka Asian Art Triennale 1999, (Fukuoka Asian art Museum, 1999); The 2nd 
Fukuoka Asian Art Triennale, 2002, "Imagined Workshop", (Fukuoka Asian Art Museum, 2002). See also: Masahiro Ushiroshoji, Asian Collection 50: From the Collection of the Fukuoka Asian Art Museum, (Fukuoka Asian Art Museum, n.d).

23 Hou Hanru, "Facing the wall of the future" in Caroline Turner and Rhana Devenport (eds), Present Encounters: Papers from the Conference of the Second Asia-Pacific Triennial of Contemporary Art 1996, Queensland Art Gallery and Griffith University, (Brisbane: Queensland Art Gallery, 1997), pp. 137-141.

24 Masahiro Ushiroshoji, "The APT and Fukuoka: A Comparison”, in Artlink, vol. 20, no.2, July 2000, p.72.

25 Masahiro Ushiroshoji, et al., The Birth of Modern Art in South East Asia: Artists and Movements, (Fukuoka Art Museum, 1997).
26 Masahiro Ushiroshoji, "Looking for Channels of Hope: The Art Exchange programme of the 1st Fukuoka Triennale", in Document of Art Exchange Programme, (Fukuoka Asian Art Museum, 1999), p. 5.

Note: The article is also based on interviews with Ma Chengyuan, Hou Hanru, Kenji Yoshida, Masatoshi Kubo, Kazuyoshi Ohtsuka, Masahiro Ushiroshoji, Amareswar Galla, as well as visits to the museums over the years. This article is related to an Australian Research Council funded research project, "The Other Within", on Asia-Pacific museums which includes the National Museum of Australia, and which will culminate in a major conference at the Humanities Research Centre, The Australian National University, in early 2004. 